\title{
Cenozoic evolution of the Vietnamese coastal margin
}

\author{
Michael B.W. Fyhn, Lars Henrik Nielsen and Lars Ole Boldreel
}

A series of Cenozoic basins fringes the Vietnamese coastal margin, often characterised by more than $10 \mathrm{~km}$ of sedimentary infill (Fig. 1). Greater parts of the margin are still in an early explorational state, although significant petroleum production has taken place in all but the southern Song Hong and the Phu Khanh Basins. This has increased the need for a fundamental understanding of the processes behind the formation of the basins, including analyses of potential source rocks.

The basins fringing the Indochina Block provide excellent evidence of the geological evolution of the region, and the basin geometries reflect the collision of India and Eurasia and the late Cenozoic uplift of south Indochina (Rangin et al. 1995a; Fyhn et al. in press). In addition, the basins provide evidence of regional Palaeogene rifting and subsequent Late Palaeogene through Early Neogene sea-floor spreading in the South China Sea. Apart from the regional Cenozoic tectonic record, the basins contain a high-resolution climatic record of South-East Asia due to the high depositional rates, changing depositional styles and large hinterland of the basin (Clift $e t$ al. 2004).

\section{Background}

Since 1995 the Geological Survey of Denmark and Greenland (GEUS) and the Department of Geography and Geology, University of Copenhagen, have operated jointly in Vietnam aiming to improve the local geoscientific capacity. The work is part of the ENRECA project (Enhancement of Research Capacity in Developing Countries), funded by the Danish International Development Agency (DANIDA). This part of the ENRECA project focuses on an assessment of the hydrocarbon potential of the Vietnamese continental margin, and al. (in press) has led to basin evaluations of the Song Hong and the Phu Khanh Basins (Fig. 1), and to a series of both Vietnamese and Danish M.Sc. projects (Nielsen et al. 1999; Nielsen \& Abatzis 2004; Andersen et al. 2005; Boldreel et al. 2005; Fyhn et al. in press). The ongoing second phase of the project focuses both on training Vietnamese M.Sc. and Ph.D. students and on evaluating the hydrocarbon potential of the Vietnamese part of the Malay and Khmer Basins, as well as

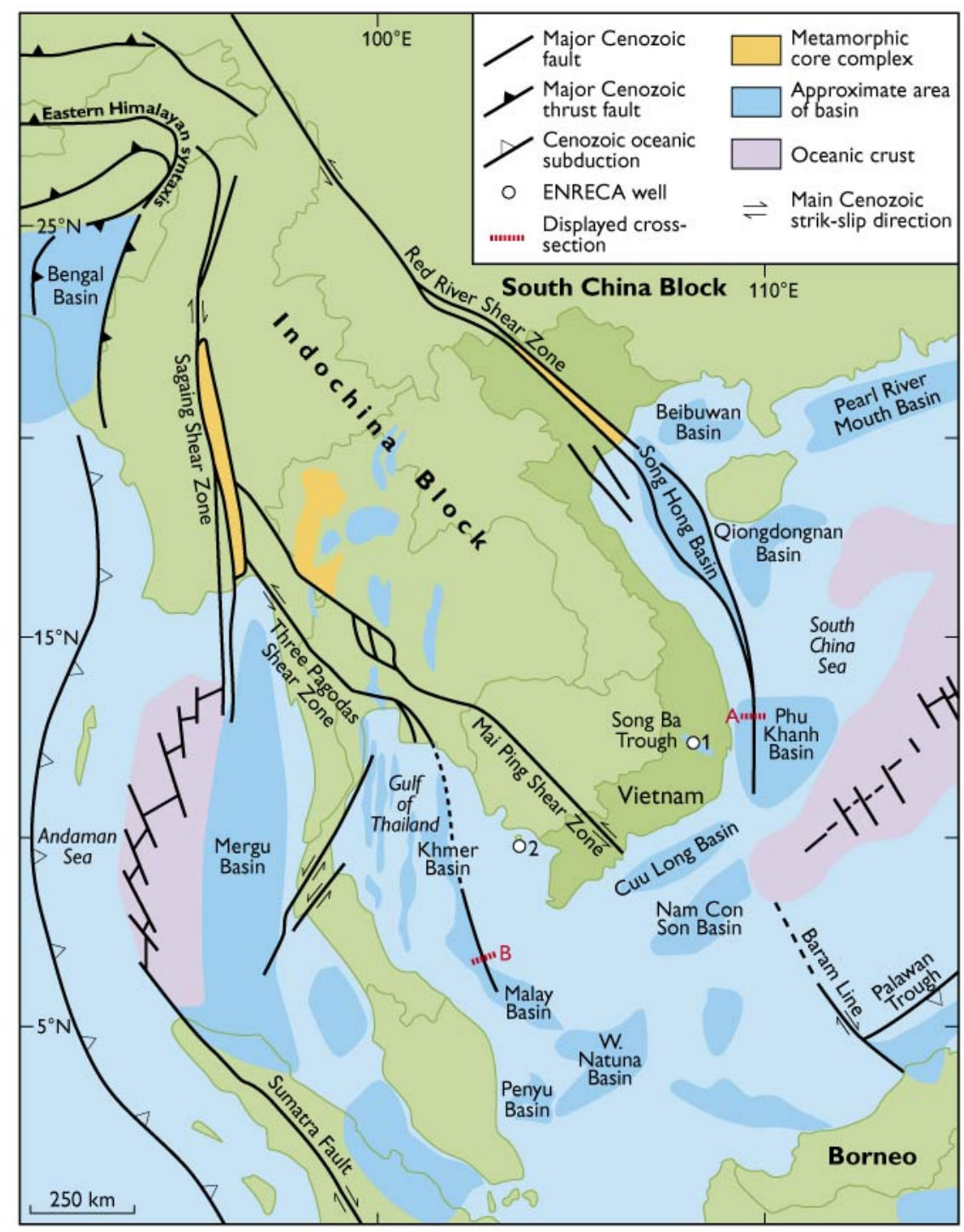

Fig. 1. Map showing major Cenozoic basins and oceanic crust and simplified Cenozoic structural features. A: cross-section shown in Fig. 3. B: cross-section shown in Fig. 4. Modified from Fyhn et 


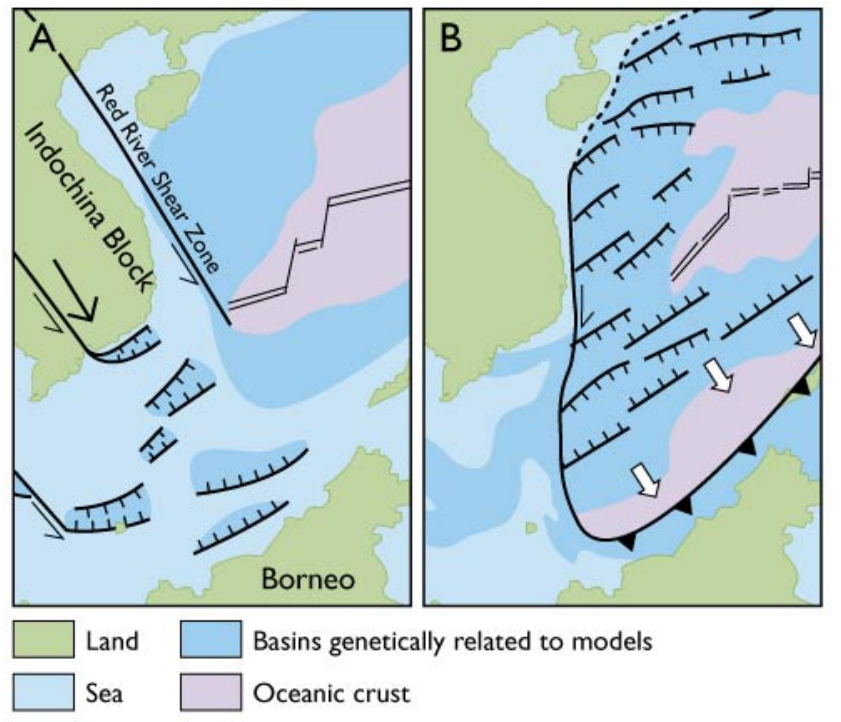

Fig. 2. Conceptual models of the two basic theories initially proposed for the formation of the South China Sea (Tapponier et al. 1982; Taylor \& Hayes 1983). Later studies have suggested various integrations of the two models (Hall 2002; Morley 2002; Fyhn et al. in press). A: The pullapart model suggests rifting and subsequent sea-floor spreading as a result of a complex left-lateral pull-apart mechanism. B: The subduction model suggests rifting and subsequent sea-floor spreading as a result of the subduction of old oceanic lithosphere beneath Borneo. Note that both models infer a transform zone along the central and south Vietnamese margin but with opposite relative sense of motion. Modified from Tapponier et al. (1982) and Taylor \& Hayes (1983).

the Mesozoic strata underneath and shoreward of these basins. Sampling of source rocks and oil seeps and drilling of two $500 \mathrm{~m}$ deep, fully cored wells (ENRECA-1 and 2, Fig. 1) as well as acquisition of shallow seismic data have been carried out as part of the basin evaluations (Bojesen-Koefoed $e t$ al. 2005; Petersen et al. 2005). Furthermore, a broader analysis of the structure and stratigraphy of the entire Vietnamese margin is being carried out as a separate Ph.D. study funded by the University of Copenhagen.

\section{Tectonic models}

The Indochina Block is situated immediately south-east of the eastern Himalayan syntaxis. The Himalayan Orogeny thus had a major impact on the structural evolution of Indochina, leading to major north-west-south-east crustal shortening in the north and to significant lateral movements along shear zones transecting and bordering the Indochina Block (Fig. 1; Morley 2002). Some of the largest shear zones are the north-west-trending Red River, Mai Ping and Three Pagodas Shear Zones. South-eastward displacement and rotation of Indochina and adjacent areas produced a total left-lateral offset of several hundreds of kilometres along the three shear zones (Hall 2002). Tapponnier et al. (1982) suggested that the South China Sea and its marginal basins formed due to complex pull-apart mechanisms in response to these left-lateral displacements (Fig. 2A). Alternatively, Taylor \& Hayes (1983) suggested that the formation of the South China Sea was a result of a southward subduction of ocean crust beneath Borneo (Fig. 2B). One of the major differences between the two models is that the subduction model predicts right-lateral displacement across a large part of the Vietnamese margin, whereas the pull-apart model is associated with a left-lateral transform along the margin.

\section{The offshore Red River Shear Zone}

The most extensive of the Indochinese left-lateral shear zones is the Red River Shear Zone that passes through South China and northern Vietnam into the Song Hong Basin. Seismic studies of the almost $20 \mathrm{~km}$ deep Song Hong Basin indicate that the basin formed in response to major Palaeogene leftlateral offset along the seaward continuation of the Red River Shear Zone (Rangin et al. 1995a; Nielsen et al. 1999; Andersen et al. 2005). Recent studies show that the shear zone continues along the Vietnamese coast in the Phu Khanh Basin further south (Fig. 1; Fyhn et al. in press). The shear zone runs along the western boundary of the Phu Khanh Basin

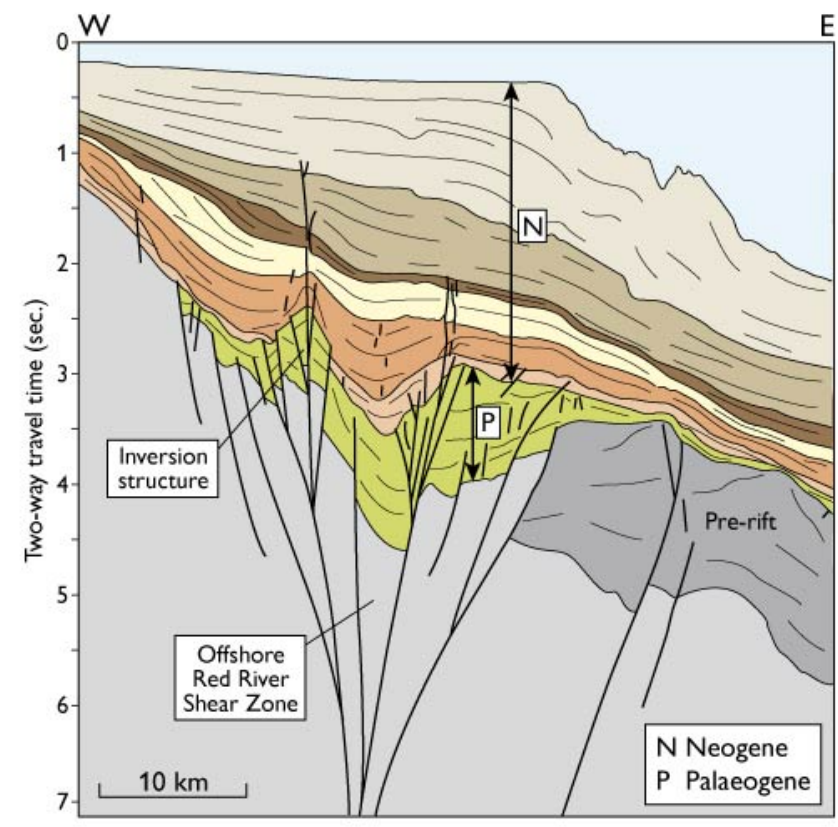

Fig. 3. Cross-section of the northern Phu Khanh Basin transecting the offshore continuation of the Red River Shear Zone. Timing of the deformations shows Palaeogene left-lateral movement followed by moderate right-lateral inversion during the early Neogene. The structural cut-off of the pre-rift sequence towards the shear zone is interpreted to be a result of the large left-lateral movement along the zone (see Fig. 1 for location). 
forming a major rift structure filled by thick Palaeogene synrift deposits (Fig. 3). Left-lateral transtension ended during latest Oligocene time in the Phu Khanh Basin, but was followed by earliest Miocene structural inversion. This is interpreted to reflect a change from intense left-lateral transtension to modest right-lateral movements along the seaward extension in the Red River Shear Zone in the basin, corroborated by a study by Rangin et al. (1995b) showing that left-lateral, coast-parallel wrench faults onshore have been inverted by right-lateral movements. The latest Palaeogene termination of left-lateral movement along the offshore part of the Red River Shear Zone in the Phu Khanh Basin does not support Neogene sea-floor spreading in the South China Sea as a result of left-lateral pull-apart. Consequently, Neogene seafloor spreading cannot have been caused by left-lateral pullapart, but was probably forced by subduction of older oceanic crust beneath Borneo. Palaeogene rifting along the Vietnamese margin was, on the other hand, greatly influenced by left-lateral transtension.

\section{The offshore Three Pagodas Shear Zone}

Rifting in the Malay and Khmer Basins south-west of Vietnam was originally linked to left-lateral transtension across a seaward extension of the Three Pagodas Shear Zone (Fig. 1; Tapponnier et al. 1982). Later models suggested right-lateral faulting along the fault zone as the forcing mechanism (Polachan \& Sattayarak 1989), or a combination of forces related to the Indochina extrusion and extension caused by subduction roll-back (Morley 2001), or mantle plume emplacement (Ngah et al. 1996).

Seismic structural analysis of the Vietnamese part of the Malay and Khmer Basins indicates that rifting mainly took place during the Palaeogene, and was controlled by a steep, north-north-west-trending, downward steeping master fault, which is flanked by smaller north-west-trending conjugate normal faults (Fig. 4). The master fault offsets the basement with up to more than $2 \mathrm{sec}$. TWT and transects the entire study region striking towards the point at which the Three Pagodas Shear Zone enters the Gulf of Thailand. The master fault is therefore interpreted as an offshore fault strand of the Three Pagodas Shear Zone. The fault characteristics indicate Palaeogene left-lateral transtension and thus support a close relation between extrusion of Indochina and rifting in the two basins.

\section{Depositional trends}

Sea-floor spreading in the South China Sea did not start until the middle Oligocene, and Palaeogene syn-rift sedimentation was therefore dominated by alluvial and lacustrine deposi-

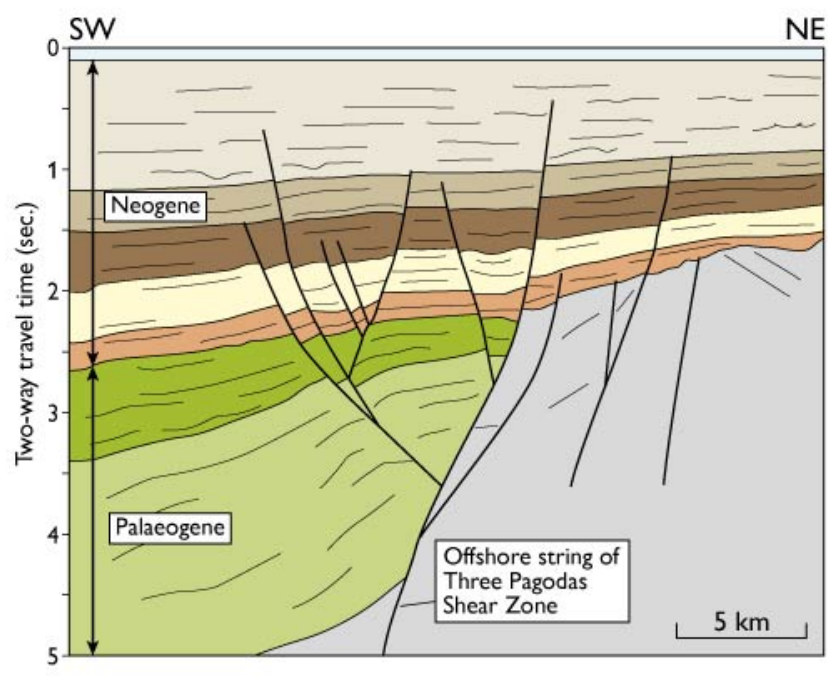

Fig. 4. Cross-section of the Vietnamese part of the Malay Basin which transects a fault strand of the seaward continuation of the Three Pagodas Shear Zone. The main offset along the major fault occurred during Palaeogene times as left-lateral transtension forced by the indentation of India into Eurasia (see Fig. 1 for location).

tion. In the Song Hong Basin a gradual marine transgression of the margin started after the onset of sea-floor spreading. During initial transgression siliciclastic deposition in estuaries and narrow marine pathways dominated larger parts of the basins, and carbonate growth took place on inundated highs. Open marine conditions prevailed in most basins during Neogene times as sea-floor spreading propagated to its maximum south-western extension. Extensive carbonate growth took place on many intra- and interbasinal highs south of and along the Vietnamese margin up to $c .16^{\circ} \mathrm{N}$ during the Neogene, favoured by the open marine environment and climatic conditions. In contrast, sediment supply kept pace with subsidence in most parts of the Malay and Song Hong Basins, preventing long-lasting periods of open marine sedimentation.

During Late Neogene time, central and southern Indochina were thermally uplifted, thus significantly increasing the siliciclastic input to the marginal basins. The increased terrigenous sediment supply inhibited widespread carbonate growth off southern and central Vietnam and resulted in the progradation of a distinct shelf slope, which has led to the present outline of the margin.

\section{Source rocks}

One of the main risk factors regarding petroleum exploration in the Vietnamese offshore basins is the presence of adequate source rock intervals. Onshore data from the ENRECA-1 core through the Song Ba Trough in central Vietnam show, however, that thick intervals of excellent oil- and gas-prone lacustrine mudstone and humic coals may develop even in 
small basins characterised by high sediment input. Although the Song Ba Trough is an order of magnitude smaller than the Vietnamese offshore basins, seismic data in the latter show apparent depositional similarities suggesting the presence of similar high-quality source rocks in the offshore basins (Nielsen et al. 2007; Fyhn et al. in press). In addition, seismic facies analysis as well as oil and gas compositions indicate that other source rock types, such as Neogene fluvio-deltaic coals, carbonaceous shales and fore-reef marls are present in some of the basins and thus testify to the great petroleum potential of the Vietnamese margin (Bojesen-Koefoed et al. 2005; Fyhn et al. in press).

\section{Acknowledgements}

This study is a Ph.D. project funded by the Faculty of Natural Science at the University of Copenhagen to the first author. Funding to the ENRECA project was given by the Danish Ministry of Foreign Affairs through DANIDA. Vietnam Petroleum Institute (PetroVietnam) is thanked for providing the seismic reflection and well data and giving permission to publish these.

\section{References}

Andersen, C., Mathiesen, A., Nielsen, L.H., Tiem, P.V., Petersen, H.I. \& Diem, P.T. 2005: Evaluation of petroleum systems in the northern part of the Cenozoic Song Hong basin (Gulf of Tonkin), Vietnam. Journal of Petroleum Geology 28, 167-184.

Bojesen-Koefoed, J.A., Nielsen, L.H., Nytoft, H.P., Petersen, H.I., Dau, N.T., Hien, L.V., Duc, N.A. \& Quy, N.H. 2005: Geochemical characteristics of oil seepages from Dam Thi Nai, central Vietnam: implications for exploration in the offshore Phu Khanh Basin. Journal of Petroleum Geology 28, 3-18.

Boldreel, L.O. et al. 2005: The Phu Khanh Basin - aspects of structural evolution and hydrocarbon potential. Science-technology conference: 30 years Vietnam petroleum industry - new challenges and opportunities, 24-25 August 2005. Hanoi, Vietnam: PetroVietnam (CD-ROM).

Clift, P.D., Layne, G.D. \& Blusztajn, J. 2004: Marine sedimentary evidence for Monsoon strengthening, Tibetian uplift and drainage evolution in East Asia. In: Clift, P.D. et al. (eds): Continent-ocean interactions within East Asian marginal seas. Geophysical Monograph Series 149, 235-254.

Fyhn, M.B.W. et al. in press: Geological evolution, regional perspectives and hydrocarbon potential of the northwest Phu Khanh Basin, offshore central Vietnam. Marine and Petroleum Geology.
Hall, R. 2002: Cenozoic geological and plate tectonic evolution of SE Asia and the SW Pacific: Computer-based reconstructions, model and animations. Journal of Asian Earth Sciences 20, 353-431.

Morley, C.K. 2001: Combined escape tectonics and subduction rollback-back arc extension: a model for the evolution of Tertiary rift basins in Thailand, Malaysia and Laos. Journal of the Geological Society (London) 158, 461-474.

Morley, C.K. 2002: A tectonic model for the Tertiary evolution of strikeslip faults and rift basins in SE Asia. Tectonophysics 347, 189-215.

Ngah, K., Madon, M. \& Tjia, H.D. 1996: Role of pre-Tertiary fractures in formation and development of the Malay and Penyu Basins. In: Hall, R. \& Blundell, D. (eds): Tectonic evolution of Southeast Asia. Geological Society Special Publication (London) 106, 281-289.

Nielsen, L.H. \& Abatzis, I. 2004: Petroleum potential of sedimentary basins in Vietnam: long-term geoscientific co-operation with the Vietnam Petroleum Institute. Geological Survey of Denmark and Greenland Bulletin 4, 97-100.

Nielsen, L.H., Mathiesen, A., Bidstrup, T., Vejbæk, O.V., Dien, P.T. \& Tiem, P.V. 1999: Modeling the hydrocarbon generation in the Cenozoic Song Hong basin, Vietnam: a highly prospective basin. Journal of Asian Earth Sciences 17, 269-294.

Nielsen, L.H., Petersen, H.I., Thai, N.D., Duc, N.A., Fyhn, M.B.W., Boldreel, L.O., Tuan, H.A., Lindstöm, S. \& Hien, L.V. 2007: A Middle-Upper Miocene fluvial-lacustrine rift sequence in the Song Ba Rift, Vietnam: an analogue to oil-prone, small-scale continental rift basins. Petroleum Geoscience 13, 145-168.

Petersen, H.I., Tru, V., Nielsen, L.H., Duc, N.A. \& Nytoft, H.P. 2005: Source rock properties of lacustrine mudstones and coals (Oligocene Dong Ho Formation), onshore Song Hong Basin, northern Vietnam. Journal of Petroleum Geology 28, 19-38.

Polachan, S. \& Sattayarak, N. 1989: Strike-slip tectonics and the development of Tertiary basins in Thailand. In: Thanasuthipitak, T. (ed.): Proceeding of the international symposium on intermountain basins: geology and resources, 243-253. Chiang Mai, Thailand: University Press.

Rangin, C., Klein, M., Roques, D., Le Pichon, X. \& Trong, L.V. 1995a: The Red River fault system in the Tonkin Gulf, Vietnam. Tectonophysics 243, 209-222.

Rangin, C., Huchon, P., Le Pichon, X., Bellon, H., Lepvrier, C., Roques, D., Hoe, N.D. \& Quynh, P.V. 1995b: Cenozoic deformation of central and south Vietnam. Tectonophysics 235, 179-196.

Tapponier, P., Peltzer, G., Le Dain, A.Y., Armijo, R. \& Cobbold, P. 1982: Propagating extrusion tectonics in Asia: new insights from simple experiments with plasticine. Geology 10, 611-616.

Taylor, B. \& Hayes, D.E. 1983: Origin and history of the South China Sea Basin. In: Hayes, D.E. (ed.): The tectonic and geologic evolution of Southeast Asian seas and islands 2. Geophysical Monograph Series 27, 23-56.

\section{Authors' addresses}

M.B.W.F. \& L.O.B., Department of Geography and Geology, University of Copenhagen, Øster Voldgade 10, DK-1350 Copenhagen K, Denmark. E-mail: fybn@geol.ku.dk

L.H.N., Geological Survey of Denmark and Greenland, Øster Voldgade 10, DK-1350 Copenhagen K, Denmark. 